\title{
BIOETHICS IN THE 21ST CENTURY: CHALLENGES AND PERSPECTIVES
}

\author{
Grebenshchikova EG $\otimes$, Chuchalin AG
}

Pirogov Russian National Research Medical University

\begin{abstract}
In this article, the authors review the role of bioethics in the processes of risk communication and socio-humanistic support for innovative development of technoscience, and analyze its commitment to the concepts of precaution and prevention. More focus is put on certain ethical challenges of the $21^{\text {st }}$ century associated with the development of artificial intelligence, deep learning in medicine, genome editing and 'new parenthood' practices. They have exploited the potential of bioethics in ethical and axiological reflection on the prospects of healthcare far-reaching reforms and in sociohumanistic assessment of transformed ideas about the human nature, family connections and established social order. It is shown that the experience of complex problem discussion and solving alongside with advisory mechanisms and bioethical procedures respond to pressing challenges of biotechnoscience and will be in demand in future.
\end{abstract}

Key words: bioethics, artificial intelligence technologies, new reproductive technologies, human genome editing, global challenges in bioethics.

$\bowtie$ Correspondence should be addressed: Elena G. Grebenshchikova

Ostrovityanova st., 1, Moscow,117997, Russia; aika45@ya.ru

Received: 08.04.2021 Accepted: 25.05.2021 Published online: 25.06.2021

DOI: $10.24075 /$ medet.2021.012

\section{БИОЭТИКА В ХХІ ВЕКЕ: ВЫЗОВЫ И ПЕРСПЕКТИВЫ}

\author{
Е. Г. Гребенщикова $\bowtie$, А. Г. Чучалин
}

Российский национальный исследовательский медицинский университет имени Н. И. Пирогова, Москва

\begin{abstract}
В статье рассматривается роль биоэтики в процессах коммуникации рисков и социогуманитарного сопровождения инновационного развития технонауки, анализируется её ориентация на идеи предосторожности и превентивные стратегии. Особое внимание уделено этическим вызовам XXI века, связанным с развитием технологий искусственного интеллекта и глубокого обучения в медицине, а также технологий редактирования генома и практик «нового родительства». Раскрыт потенциал биоэтики в этико-аксиологической рефлексии перспектив радикальных преобразований здравоохранения и в социогуманитарной оценке трансформации представлений о природе человека, семейных связях и сложившемся социальном порядке. Показано, что опыт обсуждения и решения сложных проблем, а также совещательные механизмы и процедуры биоэтики отвечают не только актуальным вызовам биотехнонауки, но и будут востребованы в будущем
\end{abstract}

Ключевые слова: биоэтика, технологии искусственного интеллекта, новые репродуктивные технологии, редактирование генома человека, глобальные вызовы в биоэтике.

$\bigotimes$ Для корреспонденции: Гребенщикова Елена Георгиевна ул. Островитянова, д. 1, г. Москва, 117997, Россия; aika45@уa.ru

Поступила: 08.04.2021 Статья принята к печати: 25.05.2021 Опубликована онлайн: 25.06.2021

DOI: $10.24075 /$ medet.2021.012

\section{INTRODUCTION}

Bioethics first emerged in the second half of the last century following two basic tendencies. The first tendency was associated with ethical implications in clinical practice, whereas the second one was subject to 'the need of human beings to be well informed about the numerous ethical dilemmas triggering breathtaking progress in biological sciences and their biotechnological applications' [1]. Today, bioethics is an interdisciplinary field of research, academic discipline and social institution of ethical and, in a broader sense, sociohumanistic examination targeted at a comprehensive assessment of biomedical innovations. These comprise ethics committees and commissions, which operate both at the local (ethics committees of research institutions) and national/international levels (as a part of agencies of the United Nations, European Union, European Council, Parliaments, etc.). The Universa Declaration on Bioethics and Human Rights adopted by the General Conference of UNESCO on 19 October 2005 recognized the role of these institutions in universal management mechanisms [2]. In various countries, the nature of these institutions is dependent on sociocultural context such as regulations, values and social attitudes, which are largely explaining why, for instance, a patient's right to refuse lifesustaining treatment is legally justified in some regions (states and countries) and invalid in others.

\section{BIOETHICS AND BIOTECHNOSCIENCE RISK COMMUNICATION}

The issues of bioethics are a constant source of public concern. This points at a specific role of bioethics in public communication of biomedicine and technoscience risk. Responding to dishonorable things in medical practice and to public concern for how research findings can be used, bioethics is a way and location to accommodate opinions of scientists, doctors, theologists, lawyers, and ethics experts. Many issues are addressed in a proactive way, expanding horizons of moral responsibility in the best interests of the future. We can't yet alter the genes of future children or imprint consciousness into an electronic device or replace hospital doctors by robots, but the experience of global disasters and turmoil of the $20^{\text {th }}$ century urged us to reconsider not just the scope and forms of human responsibility amid rapid development of science and technology but also our attitude to remote consequences of irresponsible use of modern technologies. 
In terms of theory, Hans Jonas, a German-born American philosopher, conceptualized the need of transition from ex post responsibility to ex ante responsibility in the second half of the last century by offering the new 'ethics of anticipation and responsibility' [3]. He assumed that the traditional ethical system was limited to the neighbor effect in the 'here and now'; force and knowledge of modern civilization should, however, make 'heuristics of fear' hold the central place in moral reflection. According to Jonas, the sources of our fear and undesirable scenarios of the future will bring the understanding of what 'we value indeed' steering the technological civilization in the right ethical direction.

Commitment of bioethics to the future is seen in the attempts to deal with cases like wrongful life suits. Children with severe hereditary diseases blame doctors, who could predict that the children would have a bad quality of life, but failed to inform their parents of a possible abortion. The capacity of medicine to predict the risks for the health of future children in such a surprising way turned into an unpredictable reaction of the children, claiming that their 'life is not worth living'. Who should select between a lack of life and life itself, the value of which is compromised from the very beginning? How should this be done and which moral coordinates have to be followed? From the perspective of bioethics, the discussion is deprived of any sense, as it is impossible to estimate the future child's sufferings [4]. The interest hereto is, however, heightened due to the attempt of looking behind the horizon of the present and understanding which risks and rewards are linked to any moral decision or innovation using a thought experiment (an actual bioethical method). At the same time, the research interest is focused both on separate technologies such as editing the human genome, and on ethical and philosophical issues of the 'future human nature'.

Starting from the Human Genome International Project, bioethics and social technical assessment are assigned a key role in socio-humanistic support for technoscience innovation development. According to P. D. Tishchenko, 'today, any more or less serious biological and medical project comprises sociohumanistic reflection accompanying and ensuring socialization of innovative achievements' [5]. The programs were responsible for the formation of a language of interdisciplinary and constructive discussion of occurring issues, specific layer of ethical and philosophical knowledge, and evident resource of soft management, which eliminates the gaps in regulatory activity and doesn't require long-term adjustments at the level of national or international legislation.

In this context, it is also important to note the transition from analysis of consequences to the strategies of forward assessment of new technologies. In the first case, bioethical approaches of the Human Genome Project were clearly determined, whereas the Human Brain Project initiated in 2013 was focused on the logic of caution and forward response to possible challenges. This approach is more than just a wish to foresee possible risks and perspectives, it is also an attempt to timely oppose technological inevitability to rational, conscious and responsible choice. However, scientists can't make an independent choice any longer, as interests of the society have to be respected.

Commitment of these programs to social measurements is associated with the so-called turn for a dialogue in science. According to S. Franklin, an investigator from Cambridge, this was the reason why bioethics was similar to the initiatives of public participation in scientific decision-making. 'Politicians, interviewers, and governmental bodies responsible for arrangement of ethics consultation on issues like mitochondrial donation are now making assessments formerly made by experts in bioethics. Journal editors, financial institutions, grant review commissions and politicians are new experts in bioethics' [6]. The author claims that '... everyone has to be an ethicist now' [6].

The article by S. Franklin initiated another discussion devoted to the role of bioethics in social communication of risks associated with new biomedical technologies and in management of science and technologies. However, it played out in fresh colors during the pandemic when shortcomings and ill-preparedness of national healthcare systems updated certain issues that were traditional for clinical ethics and that have remained in the periphery of investigators' interests for a long time. Distribution of scarce healthcare resources was definitely not the only moral issue, though it reminded that searching moral support in this unstable world is difficult and that medical decisions require ethics support. At the same time, there was a widely accepted position. According to it, no decision may be taken by one man only. This can reduce the risk of outrage and 'guarantee sequence, justice and transparency of decisions'. Then the community can comprehend the purpose of any assortment protocol and how it will be used, and be sure that it is used correctly [7].

It is also worth of note that bioethics influenced the formation of nanoethics, neuroethics and IT ethics which determined ethical dimensions of NBIC-convergence and development of complex approaches to ethical reflection of biotechnoscience. Thus, 'accidental findings' of MRI-guided brain research are combined in discussions of neuroethicists and bioethicists. Who and how must inform a volunteer/patient of the finding? How can collaboration between doctors, investigators and patients be built?

An attempt to reveal ethics challenges of artificial intelligence (Al) and deep learning (DL) technologies in medicine results in another complex set of issues. The challenges seem interesting not only because of the issues arising when IT technologies and biotechnologies converge, but also because they show the specific nature of 'grand challenges' in bioethics alongside with technologies of genome editing and practices of 'new parenthood'. The interest is not limited by discussions of experts and involved public members, and attracts close attention of international institutions (UNESCO, the Committee on Bioethics of the Council of Europe, etc.).

The issue of grand challenges became part of bioethics under the 'Grand Challenges in Global Health' initiative from the Gates Foundation launched in 2003 in collaboration with the US National Institutes of Health. After that, they turned into the tool, which inspired the international society of scientists to achieve certain predetermined global purposes with social, political and technical aspects [8]. They are associated with a number of socio-humanistic issues which could be settled using the procedures and institutions of bioethics by focusing on the parameters of social and moral acceptability and determining the paths of technoscience stable development.

\section{ETHICAL CHALLENGES OF THE 21ST CENTURY}

\section{Al and Deep Learning}

Artificial intelligence (Al) and machine learning are capable to fundamentally change healthcare and system of medical services [9] at the institutional, research and clinical levels by, in particular, improving patient care, medical recommendation 
compliance control, etc. Utilizing complex algorithms for data processing and based on the experience of numerous specialists, Al systems are superior to any doctor as far as decision making time and scope of the data considered go. Thus, it took 10 minutes for IBM's Watson Al to diagnose a rare form of leukemia in a patient by comparing her genetic changes with the database of 20 million oncological research papers. As a result, doctors from the Tokyo University could make a correct diagnosis and prescribe a necessary treatment [10].

Today, the basic Al advantage is related to the possibility of using deep learning based on a large amount of data for diagnostic and prognostic purposes. Gradual engagement of automated systems into clinical practice, however, results in a set of complicated questions. Will Al implementation result in the loss of competencies and skills, reestimation of clinical thinking as a precondition for high professionalism in medicine? Will the automated systems assist or replace specialists? How can Al development perspectives be applied in medical education?

Specialists in bioethics have to deal with an important task of taking into account a broad range of occurring ethical issues. For instance, high expectations are set for the development of new pharmaceuticals where the use of $\mathrm{Al}$ is expected to bring about significant progress [11]. Al can also successfully recruit volunteers and patients for clinical trials. The advantage of using big data by $\mathrm{Al}$ can, however, serve as a discriminating factor with rare diseases [12].

The issue of responsibility is equally complicated. Who must be responsible for mistakes: doctors, system developers or clinics? In the majority of cases, it will take time to discover the mistakes, which, as a consequence, can impact more than one patient. At the same time, unrecorded parameters can be the reason for that. This occurred, for example, when a sequence of clinic activities during a machine learning based decision support system (ML-DSS) development was underestimated. The system aimed at a mortality risk prediction in 14199 patients with pneumonia to stratify them according to the risk level. High risk required hospitalization, and low risk meant outpatient care. According to ML-DSS estimation, patients with pneumonia and asthma fell within the low-risk group, whereas for patients with pneumonia only it was quite the opposite. How could asthma be a protective factor? It wasn't the algorithm of decision making that created a problem. The point was that patients with a history of pneumonia and asthma were sent directly to ICUs to prevent complications. Thus, the level of mortality was lower in patients with pneumonia and asthma as compared with those with pneumonia only $(5.4 \%$ and $11.3 \%$, respectively). The MLDSS failed to rely on the context and interpreted the presence of asthma as a protective variable [13]. The impossibility to consider all significant facts and parameters during development of similar systems can result in other contextual errors, while overdependence on the ML-DSS will increase the risk of failures. Thus, the use of Al programs with a large potential of human error correction, improving the accuracy of medical diagnosis and quality of healthcare can ultimately lead to a reverse situation, when a large number of imprecisions and errors will have an effect on numerous patients. It is not accidental that, according to some authors, modern medicine may not be developed following the 'or-or' logics (a doctor or an automated system): 'when human and machine intelligence strive to accomplish the same task, we must be ready to use any approach enabling the exact and reliable accomplishment of the task. Ironically, the most difficult task set by the early $\mathrm{Al}$ in medicine remains totally human and requires to be aware of itself and its limitations, control any forms of self-confidence, rely upon the assistance of others (even machines) if necessary and always try to do its best' [14].

Another worry is that a constant growth of doctors' dependence on automated machines can result in the lack of experience, loss of important competencies, which make clinical thinking and true professionalism impossible. The last one includes special knowledge, competencies and personal qualities (compassion, patience, etc.) summarized by A. M. Bekhterev as follows: 'If a patient doesn't feel better after chatting with a doctor, then the doctor is failing in his job'. Will patients feel better after their interaction with a machine taking medical decisions? Trust is another problem of a patientphysician relationship. The assertion that 'a robot is better than a doctor' can be based on dissatisfaction with the quality of medical services, unsuccessful experience of interaction with a doctor, and many other factors, but not on trust in new technologies.

\section{Human genome editing}

The issues of human genome editing were the center of bioethical discussion in 2015 following the experiment of Chinese scientists in cells from beta-thalassemia patients. They managed to introduce changes in 4 of 86 fertilized eggs using the most effective CRISPR/Cas9 technology of genome editing. This resulted both in hopes to solve numerous medical issues and serious concerns in ethical, social and legal risks. Discussion of the latter in the same year formed the basis of agenda of two international activities such as meetings of the Committee on Bioethics of the Council of Europe and International Summit on Human Genome Editing where the corresponding statements were adopted. The announcement by He Jiankui, the Chinese biochemist, concerning the birth of twin girls with an edited gene, made in autumn 2018, served as a second impulse to the debate between experts and community.

By now, two problematic fields of bioethics are setting the trend for such discussions. The first group of 'technical' questions relates to safety, reliability and clinical appropriateness of using the technologies of genome editing for scientific and medical purposes. The issues will be resolved with their advances. However, the process of innovation development can't be totally deprived of ethical measurements just because no biomedical study may currently be conducted without an approval of the Ethics Committee.

The second group includes numerous ethical challenges concerning the use of genome editing technologies to make edits in somatic and embryonic human cells. Editing somatic cells faces no serious ethical concerns as the changes are not inherited by future generations and are associated with our hopes to get rid of many hereditary diseases; the studies require observance of standard ethical principles and standards. Human germline engineering is the area of greatest concern spawning the fear of using technologies for the 'dual' purpose of treatment and 'human improvement'.

A boundary between treatment and improvement was set in the report entitled Behind the Therapy: Biotechnologies and Pursuit of Happiness of the President's Council on Bioethics, the USA, where it was asserted, among other issues, that the 'dual use' of biotechnologies for treatment and purposes behind the therapy generates new and complicated problems. Considering therapy as the use of biotechnology derived pharmaceuticals for treatment and correction of disturbances 
aimed to restore normal health and working capacity, the authors of the report defined improvement as the use of biotechnologies to ensure direct intervention into 'normal' operation of a human body and mind in order to increase its functional capabilities [15]. The improving technologies include cosmetic surgery, doping in sports, academic doping, adult's and embryo's gene improvement. Thus, the World Anti-Doping Agency has already prohibited using gene doping in elite sports [16]. 'Altering the genes of future children' is yet under discussion as the challenge of the future. It is, however, difficult to ignore B. G. Yudin's opinion who considers the problem from the point of view of humanism: 'In spite of many imperfections inherent to the human race, we, however, must be extremely careful about its biotechnological (or any other) editing. It appears that we stand on the positions of humanism inasmuch as we believe that the human nature is a value and demands protection. If we consider longevity, health, or physical, mental or intellectual traits as the supreme value to achieve which a human being can be edited and a posthuman may be created, we make a step not towards superhumanism, but towards antihumanism' [17]. Thus, according to New Zealandbased bioethicist N. Agar, gene modification can be considered as an improvement if 'it makes a child better than a human being can normally be to a certain significant extent' [18].

Discussions centered around genome editing closely resemble the ones about human cloning which arose at the end of the last century, but quickly came to nothing following banning in the majority of countries. Some scientists believe that future developments of genome editing must be discussed with community. At the same time, in our strive for social consensus, it is necessary to remember that recent discussions concern both ethical context of genetics, and assisted reproductive technologies. The attitude towards a human embryo study and in vitro fertilization (IVF) significantly differs in various countries and can't be assessed with certainty.

\section{Reproductive technologies and new 'parenthood'}

Development of assisted reproductive technologies in the second half of the last century gave rise to a number of ethical problems. Their discussion led to a conflict of various moral, religious and legal approaches. Discrepancies were found in the anthropological status of the embryo, determining the moment of life beginning, legitimacy of human germ cell genetic manipulation and preservation.

Moreover, new reproductive technologies left the university rapidly and went to the private sector. In 1980, R. Edwards and P. Steptoe founded Bourn Hall Clinic (Cambridge, United Kingdom). It happened 2 years after the birth of Louise Brown, the first baby to be born as a result of in-vitro fertilization. The global market of reproductive technologies was developed rapidly as well, owing to the interest of potential parents and prohibition in some countries [19]. In this respect, we fear that demand for the birth of a gene-edited child may lead to the technology improvement, and the fear is real, more so that $\mathrm{He}$ Jiankui was interested in founding a private clinic of this kind [20]. It is obvious that mechanisms of ethical and legal regulation play a key role under these circumstances as they are taking into account both the requirements of science and technology development and its socio-humanistic measurements

The progress of assisted reproductive technologies did not only allow older reproductive age for women preserving their 'biological material' in biobanks (postponed parenthood) but also launched the practice of 'posthumous reproduction'. Storage of eggs in biobanks leads to no serious ethical objections while used because of health issues (for example, prior to a surgery), but is, however, often critized when social tasks are to be solved.

In case of posthumous reproduction, conception occurs when both parents are alive or when the genetic father or mother or even both would be deceased at the time of conception (IVF or posthumous insemination) [21]. Posthumous reproduction available around the world offers different approaches to biological material sampling in men and in women, consent practice (vital consent, no consent), and transfer of embryos after one or both parents died. For instance, 'in Israel, it is permitted to transfer cryopreserved embryos into the widow's uterus within one year after her husband deceased, even if his consent is lacking. But you can't use the embryos when the wife is dead. The postmortem use and retrieval of sperm of those soldiers died in combat is even possible, and no their preliminary consent is required. In Germany, Italy and France posthumous reproduction is prohibited, no matter whether a written informed consent is lacking or not' [21].

Another aspect of the matter consists in the use of frozen embryos for reproductive purposes after the death of one or both parents. There is no doubt that both parents aimed at a child's birth. But who can assert for one or both of them whether their choice would be the same under new circumstances? If one parent decides to transfer an embryo, the child will be born in a single-parent family, which may be considered as infliction of harm. But an attempt to correlate non-existence with the chance to live, even in a single-parent family, will inevitably generate a discord.

Posthumous reproduction substantially transforms the family institution undermining traditional social values and interrelation models. By acknowledging the right of a human being for a choice, bioethics must play a key role in the development of consent and dissent gaining procedures, and timely and complex estimation of new reproductive technologies which often outrun the possibilities of socio-humanistic expertise.

\section{CONCLUSION}

Ethical issues in artificial intelligence and genome editing, intervention in the field of human reproduction and new 'parenthood' are in the center of present public discussions and scientists' attention. In the debate presented, the boundaries of intervention into a human nature, autonomous choice and responsibility are defined, deficiencies in regulatory issues are found, the ways of new technology development in the world of CRISPR twins, autonomous cars and families without a common biological destiny are outlined. The discussions are technically outside the scope of the above problems being ultimately an attempt to answer the question about the kind of world we want to live in. An ultimate answer hereto can hardly be provided. Rapid development of biotechnologies, active implementation of IC technologies in medicine, achievements of neurosciences and synthetic biology, risks of epidemics, etc. will set the agenda of bioethical discussions in the $21^{\text {st }}$ century. However, discussion of the Human Brain Project achievements, resolving regulatory issues of using an artificial uterus for the purpose of reproduction and implantation of chips engaged in health controlling will inevitably require referral to some approved ideas of a human life value, grounds for reasonable intervention into 'the regimen of natural entity' and current social order. That is why a specific expert position of bioethicists, and theory and practice of bioethics, where the academic and publics parts intertwine in a particular way, will be in demand. 


\section{References}

1. Yudin BG. Moral', biologija, parvo. Vestnik Rossijskoj akademi nauk. 2001; 71(9): 775-83. Russian.

2. Montgomery J. Bioethics as a governance practice //Health Care Analysis. 2016; 24(1): 3-23.

3. Jonas G. Princip otvetstvennosti: Opyt jetiki dlja tehnologicheskoj civilizacii. M.: Airis-press, 2004. 479 s/ Russian.

4. Bell NK, Loewer BM. What is Wrong with 'Wrongful Life'Cases? // The Journal of medicine and philosophy. 1985;10(2): 127-146

5. Tishhenko PD. Institualizacija jeticheskoj refleksii $\vee$ social'no raspredeljonnom proizvodstve biomedicinskih znanij. Istorija i filosofija nauki v jepohu peremen: sbornik nauchnyh statej: $\vee 6$ tomah. T. 6. M., 2018; 5-7. Russian.

6. Franklin S. Ethical research-the long and bumpy road from shirked to shared. Nature. 2019; 574 (7780): 627-630.

7. Pagel C., Utley M., Ray S. Covid-19: how to triage effectively in a pandemic. BMJ Opinion. 2020. https://blogs.bmj.com/ bmj/2020/03/09/covid-19-triage-in-a-pandemic-is-even-thornierthan-you-might-think/

8. Brooks S., Leach M., Lucas H., Millstone E. Silver bullets, grand challenges and the new philanthropy. 2009 URL: http://www.ids. ac.uk/files/dmfile/STEPSWorkingPaper24.pdf.

9. Nabi J. How bioethics can shape artificial intelligence and machine learning. Hastings Center Report. 2018; 48(5): 10-13.

10. Fingas J. IBM's Watson Al saved a woman from leukemia. URL: https://www.engadget.com/2016/08/07/ibms-watson-ai-saveda-woman-from-leukemia/

\section{Литература}

1. Юдин Б. Г. Мораль, биология, право. Вестник Российской академии наук. 2001;71(9): 775-83.

2. Montgomery J. Bioethics as a governance practice. Health Care Analysis. 2016; 24(1): 3-23.

3. Йонас Г. Принцип ответственности: Опыт этики для технологической цивилизации. М.: Айрис-пресс, 2004; 479 с.

4. Bell NK, Loewer BM. What is Wrong with 'Wrongful Life'Cases? The Journal of medicine and philosophy. 1985;10(2): 127-146.

5. Тищенко П. Д. Институализация этической рефлексии в социально распределённом производстве биомедицинских знаний. История и философия науки в эпоху перемен: сборник научных статей: В 6 томах. Т. 6. М., 2018; 5-7.

6. Franklin $\mathrm{S}$. Ethical research-the long and bumpy road from shirked to shared. Nature. 2019; 574 (7780): 627-630.

7. Pagel C., Utley M., Ray S. Covid-19: how to triage effectively in a pandemic. BMJ Opinion. 2020. https://blogs.bmj.com/ bmj/2020/03/09/covid-19-triage-in-a-pandemic-is-even-thornierthan-you-might-think/

8. Brooks S, Leach M, Lucas H, Millstone E. Silver bullets, grand challenges and the new philanthropy. 2009 URL: http://www.ids. ac.uk/files/dmfile/STEPSWorkingPaper24.pdf.

9. Nabi J. How bioethics can shape artificial intelligence and machine learning //Hastings Center Report. 2018; 48(5): 10-13.

10. Fingas J. IBM's Watson Al saved a woman from leukemia. URL: https://www.engadget.com/2016/08/07/ibms-watson-ai-saveda-woman-from-leukemia/
11. Schneider $\mathrm{P}$ et al. Rethinking drug design in the artificial intelligence era //Nature Reviews Drug Discovery. 2020; 19 (5): 353-364.

12. Artificial intelligence (Al) in healthcare and research //Bioethics Briefing Note. Nuffield Council on Bioethics. 2018; 1-8.

13. Cabitza F, Rasoini R, Gensini GF. Unintended consequences of machine learning in medicine. Jama. 2017; 318 (6): 517-518.

14. London AJ. Groundhog day for medical artificial intelligence. Hastings Center Report. 2018. https://doi.org/10.1002/hast.842

15. Beyond Therapy: Biotechnology and the Pursuit of Happiness URL: http://www.vanderbilt.edu/olli/files/Beyond-Therapy-Kass.pdf

16. Brown J. Genetic doping: WADA we do about the future of 'cheating'in sport? The International Sports Law Journal. 2019; 19(3-4): 258-280.

17. Yudin BG. Transgumanizm: sverhgumaniazi ili antigumanizm? Chelovek: vyhod za predely M., 2018. 470 s. Russian.

18. Agar N. How to defend genetic enhancement. Medical enhancement and posthumanity. Springer, Dordrecht, 2008; 55-67.

19. Morrison M, de Saille S. CRISPR in context: towards a socially responsible debate on embryo editing. Palgrave Communications. 2019; 5(1): 1-9

20. Cohen J. The untold story of the 'circle of trust'behind the world's first gene-edited babies. Science. 2019. https://doi. org/10.1126/ science. aay 9400.

21. Svitnev KN. Pravovye i jetichsekie aspekty posmertnoj reprodukcii// Pravovye voprosy v zdravoohranenii. 2011; 6: 30-43. Russian.

11. Schneider P. et al. Rethinking drug design in the artificial intelligence era. Nature Reviews Drug Discovery. 2020; 19(5): 353-364.

12. Artificial intelligence (Al) in healthcare and research //Bioethics Briefing Note. Nuffield Council on Bioethics. 2018; 1-8.

13. Cabitza F, Rasoini R, Gensini GF. Unintended consequences of machine learning in medicine. Jama. 2017; 318 (6): 517-518.

14. London A. J. Groundhog day for medical artificial intelligence. Hastings Center Report. 2018. https://doi.org/10.1002/hast.842

15. Beyond Therapy: Biotechnology and the Pursuit of Happiness URL: http://www.vanderbilt.edu/olli/files/Beyond-Therapy-Kass.pdf

16. Brown J. Genetic doping: WADA we do about the future of 'cheating'in sport? The International Sports Law Journal. 2019; 19(3-4): 258-280.

17. Юдин Б. Г. Трансгуманизм: сверхгуманизм или антигуманизм? Человек: выход за пределы М., 2018. 470 с.

18. Agar N. How to defend genetic enhancement. Medical enhancement and posthumanity. Springer, Dordrecht, 2008; 55-67.

19. Morrison M, de Saille S. CRISPR in context: towards a socially responsible debate on embryo editing. Palgrave Communications. 2019; 5(1): 1-9.

20. Cohen J. The untold story of the 'circle of trust'behind the world's first gene-edited babies. Science. 2019. https://doi. org/10.1126/ science. aay 9400 .

21. Свитнев К. Н. Правовые и этичсекие аспекты посмертной репродукции// Правовые вопросы в здравоохранении. 2011; 6: $30-43$ 